\title{
Clavibacter toxicus sp. nov., the Bacterium Responsible for Annual Ryegrass Toxicity in Australia
}

\author{
IAN T. RILEY ${ }^{1+*}$ AND KATHY M. OPHEL ${ }^{2}$ \\ Field Crops Pathology Group, South Australian Department of Agriculture, ${ }^{1}$ and Department of \\ Crop Protection, The University of Adelaide, ${ }^{2}$ Waite Agricultural Research Institute,
}

Glen Osmond, South Australia 5064, Australia

\begin{abstract}
The Clavibacter sp. associated with annual ryegrass toxicity (ARGT) in Australia has been reported to differ from other Clavibacter spp. in serological properties, allozyme electrophoretic mobility, bacteriophage sensitivity, and adhesion to nematodes (Anguina spp.). To clarify its taxonomic position, eight strains of the ARGT Clavibacter sp. were compared with strains of Arthrobacter ilicis, Clavibacter iranicum, Clavibacter michiganense, Clavibacter rathayi, Clavibacter tritici, Curtobacterium flaccumfaciens, and Rhodococcus fascians. The ARGT strains were distinguishable from the other bacteria on the basis of the results of a range of biochemical tests. DNA base composition, growth factor requirements, and growth rates were also determined. A new species, Clavibacter toxicus, is proposed, with type strain CS14 (= ICMP $9525=$ NCPPB 3552).
\end{abstract}

Annual ryegrass toxicity (ARGT) often results in fatal poisoning of livestock that graze on ryegrass (Lolium rigidum Gaudin) which is infected with a toxigenic Clavibacter sp. $(1,7,18,20)$. The bacterium is carried into the grass by Anguina funesta Price, Fisher, and Kerr 1979, a parasitic nematode of ryegrass $(19,25)$. ARGT was first recorded in 1956 at Black Springs, South Australia (9), but the involvement of a toxigenic bacterium was not recognized until 1968 (18). The bacterium was found to be related to a group of Clavibacter spp. that cause similar diseases in grasses and have been partially described (17). A morphological description was published in 1977 (1). The ARGT bacterium was referred to as Corynebacterium sp. and Corynebacterium rathayi [now Clavibacter rathayi (Smith 1913) Davis et al. 1984]. Identification as Corynebacterium rathayi was presumptive and was not based on results of comparative studies (20). Since Corynebacterium rathayi is a markedly different organism in culture and strains of the ARGT bacterium were not included in the work of Davis et al. (5) in which reclassification of Corynebacterium rathayi into a new genus, Clavibacter, was proposed, the position of the ARGT bacterium needed to be clarified. An immunological study indicated that the ARGT bacterium was distinct from Corynebacterium (Clavibacter) rathayi and other coryneform plant pathogens (20). The detection of 2,4-diaminobutyric acid in its cell walls confirmed that this organism belongs in the genus Clavibacter, and it was recommended that the bacterium be known as Clavibacter sp. (20).

Further studies have confirmed that the ARGT bacterium is distinct from other Clavibacter spp. Allelic profiles determined by allozyme electrophoresis of 20 enzymes indicated that the levels of genetic difference were at least $85 \%$ between the ARGT bacterium and the other Clavibacter spp. studied and $18 \%$ or less within the 11 strains of the ARGT bacterium (24). A bacteriophage which lysed all of the strains of the ARGT bacterium tested but no other Clavibacter $\mathrm{sp}$. has been described (21). Studies of the adhesion of 35 plant-pathogenic coryneform strains (mostly Clavibacter

\footnotetext{
* Corresponding author.

† Present address: Plant Pathology Branch, Department of Agriculture, Baron Hay Court, South Perth, Western Australia 6151, Australia.
}

spp.) to seven nematode populations representing five $A n$ guina spp. showed that there were significant variations in the adhesion patterns of the strains, and this finding supported with the separation of the ARGT bacterium from other Clavibacter spp. (22).

In this paper we propose that the ARGT bacterium should be named as a new species in the genus Clavibacter. The results of comparative physiological and biochemical tests supported this proposal

\section{MATERIALS AND METHODS}

Bacterial strains. The strains which we used in this study and their origins are shown in Table 1 . Our bacterial nomenclature is the same as that used by Davis (4) in his review of the taxonomy of plant-pathogenic coryneform bacteria. All of the strains were maintained on medium 523M, which contained (per liter) $10 \mathrm{~g}$ of sucrose, $2 \mathrm{~g}$ of Casamino Acids (Difco), $2 \mathrm{~g}$ of yeast extract (Difco), $2 \mathrm{~g}$ of $\mathrm{K}_{2} \mathrm{HPO}_{4}, 0.3 \mathrm{~g}$ of $\mathrm{MgSO}_{4} \cdot 7 \mathrm{H}_{2} \mathrm{O}$, and $15 \mathrm{~g}$ of agar. The strains were grown at $26^{\circ} \mathrm{C}$ unless indicated otherwise. Cultures were kept in sterile glycerol at $-20^{\circ} \mathrm{C}$ for medium-term storage and freezedried for long-term storage.

Biochemical tests. (i) Growth and acid production from carbon sources. Medium C of Dye and Kemp (6) was used to test growth on and production of acid from carbon sources. The following carbon sources were tested at concentrations of $0.5 \%$ (wt/vol): galactose, mannitol, and mannose (Ajax Chemicals, Sydney, Australia); ethanol, inulin, and xylose (BDH Chemicals, Port Fairy, Victoria, Australia); and dulcitol (galactitol), erythritol, adonitol (ribitol), and melezitose (Sigma). Tubes were incubated at $26^{\circ} \mathrm{C}$ and examined after 7 14,21 , and 28 days for growth and acid production.

(ii) Utilization of organic acids. The modified YSA medium described by Dye and Kemp (6) was used to test utilization of sodium salts of succinate, tartrate, acetate, malonate, and glutamate $(0.2 \%$, wt/vol; BDH Chemicals). Tubes were incubated at $26^{\circ} \mathrm{C}$ and examined after $7,14,21$, and 28 days.

(iii) Maximum $\mathrm{NaCl}$ tolerance. Medium YSB of Dye and Kemp (6) containing 0 to $10 \%$ (wt/vol) $\mathrm{NaCl}$ in $1 \%$ gradations was used to test $\mathrm{NaCl}$ tolerance. Cultures were shaker incubated at $25^{\circ} \mathrm{C}$ and examined for growth after 3,7 , and 14 days. 
TABLE 1. Strains used in this study

\begin{tabular}{|c|c|c|c|}
\hline Taxon & Laboratory no. & Source $^{a}$ & Other designation(s) ${ }^{a}$ \\
\hline Arthrobacter ilicis & $\mathrm{CS}_{10}^{\mathrm{T}}$ & ICMP 2607 & ATCC $14264^{\mathrm{T}}$, ICPB CI144 ${ }^{\mathrm{T}}$, NCPPB $1228^{\mathrm{T}}$ \\
\hline Clavibacter iranicum & $\mathrm{CS}_{13}{ }^{\mathrm{T}}$ & ICMP 3496 & ICPB CI148, NCPPB $2253^{\mathrm{T}}$ \\
\hline Clavibacter michiganense subsp. insidiosum & CS20 & NCPPB 1109 & \\
\hline Clavibacter michiganense subsp. michiganense & $\operatorname{CS} 25^{\mathrm{T}}$ & NCPPB $2979^{\mathrm{T}}$ & \\
\hline Clavibacter michiganense subsp. nebraskense & $\mathrm{CS} 24^{\mathrm{T}}$ & NCPPB $2581^{\mathrm{T}}$ & \\
\hline Clavibacter rathayi & $\begin{array}{l}\text { CS5 } \\
\text { CS26 }\end{array}$ & $\begin{array}{l}\text { ICMP } 2571 \\
\text { NCPPB } 2980^{\mathrm{T}}\end{array}$ & $\begin{array}{l}\text { ATCC } 13659, \text { ICPB CR1, NCPPB } 80 \\
\text { ICMP } 2574^{\mathrm{T}}\end{array}$ \\
\hline \multirow{3}{*}{ Clavibacter tritici } & $\mathrm{CS} 4$ & ICMP 2624 & ICPB CT106, NCPPB 255, NCTC 6255 \\
\hline & CS12 & ICMP 2628 & ICPB CT104 \\
\hline & $\mathrm{CS} 21^{\mathrm{T}}$ & NCPPB $1857^{\mathrm{T}}$ & ATCC $11403^{\mathrm{T}}$, ICPB CT102 $2^{\mathrm{T}}$ \\
\hline \multirow[t]{8}{*}{ Clavibacter sp. (ARGT bacterium) } & $\mathrm{CS} 2$ & South Australia & \\
\hline & CS3 & South Australia & \\
\hline & $\mathrm{CS} 14^{\mathrm{T}}$ & South Australia & ICMP $9525^{\mathrm{T}}$, NCPPB $3552^{\mathrm{T}}$ \\
\hline & CS28 & WSM 188 & ICMP 6307 \\
\hline & CS30 & WSM 447 & \\
\hline & CS31 & WSM 455 & \\
\hline & CS33 & South Australia & ICMP 9526 \\
\hline & CS34 & South Australia & ICMP 9527, NCPPB 3553 \\
\hline \multirow{3}{*}{$\begin{array}{l}\text { Curtobacterium flaccumfaciens pv. flaccumfaciens } \\
\text { Curtobacterium flaccumfaciens pv. poinsettiae } \\
\text { Rhodococcus fascians }\end{array}$} & $\mathrm{CS}^{\mathrm{T}}$ & ICMP $2584^{\mathrm{T}}$ & NCPPB $1446^{\mathrm{T}}$ \\
\hline & CS19 & NCPPB 854 & \\
\hline & $\mathrm{CS} 27^{\mathrm{T}}$ & NCPPB $3067^{\mathrm{T}}$ & ATCC $12974^{\mathrm{T}}$, ICMP $5833^{\mathrm{T}}$ \\
\hline
\end{tabular}

a ATCC, American Type Culture Collection, Rockville, Md.; ICPB, International Collection of Phytopathogenic Bacteria, Department of Bacteriology, University of California, Davis; ICMP, International Collection of Microorganisms from Plants (formerly Plant Diseases Division Culture Collection), Plant Diseases Division, Department of Scientific and Industrial Research, Auckland, New Zealand; NCPPB, National Collection of Plant Pathogenic Bacteria, Plant Pathology Laboratory, Hatching Green, Harpenden, Hertfordshire, England; WSM, Western Australian Department of Agriculture, South Perth, Australia.

(iv) $\mathrm{H}_{2} \mathrm{~S}$ production. The method described by Fahy and Hayward (8) was used to test $\mathrm{H}_{2} \mathrm{~S}$ production from both $0.01 \%$ cysteine hydrochloride (Sigma) and $0.5 \%$ neutralized bacteriological peptone (Oxoid). Tubes containing $5 \mathrm{ml}$ of medium were inoculated and incubated with a lead acetate strip suspended over the culture. Lead acetate strips were prepared by impregnating strips of filter paper with $5 \%$ lead acetate; the strips were then air dried and autoclaved. Cultures were examined after 7,14 , and 21 days of growth at $26^{\circ} \mathrm{C}$.

(v) Starch hydrolysis. Starch hydrolysis was tested by spotting cultures onto YNA medium containing $5 \mathrm{~g}$ of yeast extract (Difco) per liter, $23 \mathrm{~g}$ of nutrient agar (Difco) per liter, and $0.2 \%$ soluble starch (Ajax Chemicals). After 7 to 14 days of incubation (depending on growth), the plates were flooded with an iodine solution containing $10 \mathrm{~g}$ of iodine per liter and $20 \mathrm{~g}$ of potassium iodide per liter.

(vi) Growth at $37^{\circ} \mathrm{C}$. Bacteria were streaked onto $523 \mathrm{M}$ agar and incubated at $37 \pm 0.5^{\circ} \mathrm{C}$ and at $26^{\circ} \mathrm{C}$ (as a positive control). The plates were examined for growth after 3,7 , and 14 days.

(vii) Gelatin hydrolysis. Duplicate tubes containing nutrient gelatin (Difco) were stab inoculated, and the tubes were assessed after $7,14,21$, and 28 days of incubation at $26^{\circ} \mathrm{C}$.

(viii) Oxygen requirements. Duplicate tubes containing $523 \mathrm{M}$ agar were stab inoculated, and after inoculation one tube of each pair was covered with $10 \mathrm{~mm}$ of sterile paraffin oil-petroleum jelly (1:1). Growth was recorded after 7 and 14 days.

(ix) Other tests. The methods of Dye and Kemp (6) were used to test catalase activity, nitrate reduction, production of acetoin, tyrosinase, and urease, and lipolysis of Tween 80 (Sigma) and cotton seed oil (Drug Houses of Australia). Oxidase activity was tested by using the methods described by Fahy and Hayward (8).

DNA base composition. DNAs from strains CS2 and CS14 ${ }^{\text {T }}$ $(\mathrm{T}=$ type strain) were prepared from cultures grown in 200 $\mathrm{ml}$ of $523 \mathrm{M}$ broth by using the method described by Hunter (11). DNA base composition was determined from the thermal denaturation point as described by Marmur and Doty (14), using $25 \mu \mathrm{g}$ of DNA per $\mathrm{ml}$ in PE buffer $(10 \mathrm{mM}$ phosphate buffer [pH 7.2], $1 \mathrm{mM}$ EDTA). Denaturation profiles were measured by using a Pye \& Unicam model 5P8-200 spectrophotometer equipped with an Accuron model SPX 876 temperature controller.

Growth factor requirements. The method used to determine growth factor requirements was modified from the method of Keane et al. (13). Bacteria from 523M agar plates were suspended in buffered saline, washed with sterile distilled water $(10 \mathrm{~min}, 3,000 \times \mathrm{g})$, and inoculated onto agar containing $0.5 \mathrm{~g}$ of $\mathrm{NH}_{4} \mathrm{H}_{2} \mathrm{PO}_{4}$ per liter, $0.5 \mathrm{~g}$ of $\mathrm{K}_{2} \mathrm{HPO}_{4}$, per liter, $0.2 \mathrm{~g}$ of $\mathrm{MgSO}_{4} \cdot 7 \mathrm{H}_{2} \mathrm{O}$ per liter, $5 \mathrm{~g}$ of $\mathrm{NaCl}$ per liter, and $1 \%$ (wt/vol) sucrose (autoclaved separately); this medium was amended with $0.1 \mu \mathrm{g}$ of biotin per $\mathrm{ml}, 0.1 \mu \mathrm{g}$ of nicotinic acid per $\mathrm{ml}, 0.2 \mu \mathrm{g}$ of calcium pantothenate per $\mathrm{ml}$, or $0.1 \%(\mathrm{wt} / \mathrm{vol})$ yeast extract (Difco). Growth was assessed after $4,7,14$, and 28 days of incubation at $26^{\circ} \mathrm{C}$.

Growth rates. The growth rates of three ARGT strains, two strains of Clavibacter tritici, and two strains of Clavibacter rathayi were determined in $523 \mathrm{M}$ broth. Bacteria from 48-h-old cultures were added to $50 \mathrm{ml}$ of broth to give an initial concentration of $1 \times 10^{6}$ cells per ml. The cells were grown on a rotary shaker at $25^{\circ} \mathrm{C}, 3 \mathrm{ml}$ of culture was removed for each sample, and the optical density at $600 \mathrm{~nm}$ was measured every $8 \mathrm{~h}$ for 6 days, by which time all of the cultures had reached saturation. The growth rates were plotted, and the time taken for each culture to grow from an optical density at $600 \mathrm{~nm}$ of 0.5 to an optical density at 600 $\mathrm{nm}$ of 1.0 was calculated.

\section{RESULTS}

Biochemical tests. The ARGT strains differed from all of the other species tested in their reactions in biochemical 
TABLE 2. Biochemical characteristics of coryneform strains

\begin{tabular}{|c|c|c|c|c|c|c|c|c|c|c|c|}
\hline Characteristic & $\underset{\substack{\text { ARGT } \\
(n=8)^{a}}}{\text { bacterium }}$ & $\begin{array}{l}\text { Clavibacter } \\
\text { iranicum }\end{array}$ & $\begin{array}{c}\text { Clavibacter } \\
\text { rathayi } \\
(n=2)\end{array}$ & $\begin{array}{c}\text { Clavibacter } \\
\quad \text { tritici } \\
(n=3)\end{array}$ & $\begin{array}{l}\text { Clavibacter } \\
\text { michigan- } \\
\text { ense subsp. } \\
\text { insidiosum }\end{array}$ & $\begin{array}{l}\text { Clavibacter } \\
\text { michigan- } \\
\text { ense subsp. } \\
\text { nebrask- } \\
\text { ense }\end{array}$ & $\begin{array}{c}\text { Clavibacter } \\
\text { michigan- } \\
\text { ense subsp. } \\
\text { michigan- } \\
\text { ense }\end{array}$ & $\begin{array}{c}\text { Arthro- } \\
\text { bacter } \\
\text { ilicis }\end{array}$ & $\begin{array}{l}\text { Curtobac- } \\
\text { terium } \\
\text { flaccum- } \\
\text { faciens } \\
\text { pv. flac- } \\
\text { cum- } \\
\text { faciens }\end{array}$ & $\begin{array}{l}\text { Curtobac- } \\
\text { terium } \\
\text { flaccum- } \\
\text { faciens } \\
\text { pv. poin- } \\
\text { settiae }\end{array}$ & $\begin{array}{l}\text { Rhodo- } \\
\text { coccus } \\
\text { fascians }\end{array}$ \\
\hline \multicolumn{12}{|l|}{ Acid produced from: } \\
\hline Adonitol & $-b$ & - & - & - & - & - & - & - & + & + & - \\
\hline Dulcitol & - & - & - & - & - & - & - & - & - & - & - \\
\hline Erythritol & - & - & - & - & - & - & - & - & - & + & - \\
\hline Ethanol & - & - & - & - & - & - & - & + & - & - & + \\
\hline Galactose & + & + & + & + & + & + & + & + & + & + & + \\
\hline Inulin & - & - & - & + & - & - & - & - & - & - & - \\
\hline Mannitol & - & - & + & + & - & + & - & + & + & + & + \\
\hline Mannose & t & + & - & + & + & + & + & + & + & + & + \\
\hline Melezitose & - & + & - & - & - & - & - & + & + & + & - \\
\hline Xylose & $+(7)$ & + & + & + & + & + & + & + & + & + & + \\
\hline \multicolumn{12}{|l|}{ Utilization of: } \\
\hline Acetate & - & - & $+(1)$ & + & - & + & + & + & + & + & + \\
\hline Glutamate & - & - & - & + & - & - & + & + & + & - & + \\
\hline Malonate & - & + & - & + & - & + & + & + & + & - & + \\
\hline Succinate & - & + & + & + & - & + & + & + & + & - & + \\
\hline Tartrate & - & - & - & - & - & + & + & - & - & - & + \\
\hline $\begin{array}{l}\text { Maximum } \mathrm{NaCl} \text { concn } \\
\text { tolerated (\%) }\end{array}$ & 1 & 2 & 3 & 4 & 3 & 5 & 5 & 5 & 8 & 8 & 6 \\
\hline Starch hydrolysis & - & + & $+(1)$ & $-(2)$ & - & + & + & - & + & + & - \\
\hline Growth at $37^{\circ} \mathrm{C}$ & - & - & - & - & - & - & - & + & + & + & - \\
\hline Gelatin hydrolysis & - & - & + & - & - & - & - & + & - & - & - \\
\hline \multicolumn{12}{|l|}{$\mathrm{H}_{2} \mathrm{~S}$ produced from: } \\
\hline Cysteine & + & + & + & + & + & + & + & + & + & + & + \\
\hline Peptone & - & + & + & + & - & + & + & + & - & - & + \\
\hline Pigmentation $^{c}$ & $\mathrm{Y}$ & $\mathrm{Y}$ & $\mathrm{Y}$ & $\mathrm{Y}$ & W & $\mathrm{O}$ & $\mathrm{Y}$ & $\mathrm{Y}$ & $\mathrm{Y}$ & $\mathrm{O}$ & $\mathrm{O}$ \\
\hline
\end{tabular}

${ }^{a} n$ is the number of strains tested. Where no number is given, only the type strain was tested.

$b+$, positive reaction; - , negative reaction. Where strains differed in their reactions, the most common reaction is indicated, and the number of strains which gave that reaction is indicated in parentheses.

${ }^{c} \mathrm{Y}$, yellow; $\mathrm{O}$, orange; $\mathrm{W}$, white.

tests (Table 2). The ARGT strains differed from the Clavibacter tritici strains in their carbon source and organic acid utilization patterns. All of the Clavibacter tritici strains produced acid from mannitol and inulin and utilized succinate, acetate, malonate, and glutamate. The Clavibacter tritici strains tolerated higher levels of $\mathrm{NaCl}(4 \%)$ in the growth medium than the ARGT strains did (1\%). The ARGT strains also differed from the Clavibacter rathayi strains in acid production. The two Clavibacter rathayi strains produced acid from mannose and mannitol, and they utilized succinate. One of the Clavibacter rathayi strains tested utilized acetate, but none of the ARGT strains did. The Clavibacter rathayi strains tolerated higher concentrations of $\mathrm{NaCl}$ in the growth medium and hydrolyzed gelatin, which the ARGT strains did not. The ARGT strains also differed from the type strain of Clavibacter iranicum in a number of respects. The Clavibacter iranicum strain produced acid from melezitose and utilized malonate, which the ARGT strains did not. The Clavibacter iranicum type strain also tolerated a slightly higher level of $\mathrm{NaCl}$ in the growth medium (Table 2). All strains of Clavibacter iranicum, Clavibacter rathayi, and Clavibacter tritici produced $\mathrm{H}_{2} \mathrm{~S}$ from peptone, while the ARGT strains did not. The ARGT strains differed from the type strains of seven other coryneform plant-pathogenic bacterial species used in this study (Table 2).

In general, the ARGT strains were more discriminating in their utilization of carbon sources and organic acids. They produced acid from only 3 of the 10 carbon sources tested and utilized none of the five organic acid sources tested. Tolerance of $\mathrm{NaCl}$ was low (1\%), and none of the strains hydrolyzed starch or gelatin. All of the ARGT strains produced $\mathrm{H}_{2} \mathrm{~S}$ from cysteine but not from peptone. All of the ARGT strains produced catalase, and none produced oxidase. Tests for urease, tyrosinase, acetoin, lipolysis of Tween 80 and cotton seed oil, and nitrate reduction performed with the ARGT strains and the type strains of Clavibacter rathayi, Clavibacter tritici, Clavibacter iranicum, and Clavibacter michiganense subsp. michiganense were all negative except for acetoin production by Clavibacter michiganense subsp. michiganense. All of the ARGT strains had an obligate requirement for oxygen. Growth of the ARGT strains was very slow, and great care had to be taken in the tests to incubate the cultures for a sufficient length of time and to avoid contamination. All eight ARGT strains tested were uniform in their responses except that one strain, strain CS28, did not produce acid from xylose while the other seven ARGT strains did.

Most of the tests performed with the other coryneform strains produced results which agreed with the results previously published by Dye and Kemp (6) and Collins and Bradbury (3). However, there were 14 instances in which the results shown in Table 2 differed from those of Davis et al. (5). In nine of these cases our results agreed with those of Dye and Kemp (6), and in four cases our results differed from the results of both studies. We also observed a differ- 
ence in acetate utilization between the two strains of Clavibacter rathayi tested. There are numerous differences in biochemical test results described in the previously published studies. Dye and Kemp noted that there were differences between strains of the same species and when some tests were repeated with a single strain. Consistent methodology for biochemical tests for this group of organisms seems to be difficult to achieve, and this observation highlights the diagnostic value of methods such as serology and bacteriophage sensitivity.

DNA base composition. The DNAs of strains CS2 and $\mathrm{CS} 14^{\mathrm{T}}$ contained 67.6 and $67.0 \mathrm{~mol} \%$ guanine plus cytosine $(\mathrm{G}+\mathrm{C})$, respectively. These values fell in the previously published range for $\mathrm{G}+\mathrm{C}$ contents of other Clavibacter spp. (i.e., 67 to $78 \mathrm{~mol} \%$ [3])

Growth factor requirement. All eight ARGT strains which we tested required the addition of $0.1 \%$ yeast extract to the growth medium. Addition of biotin alone or of biotin, nicotinic acid, and calcium pantothenate together to the minimal medium did not satisfy the growth requirements. Both the type strain of Clavibacter tritici and the type strain of Clavibacter rathayi grew with the addition of biotin alone, and the type strain of Clavibacter iranicum required the addition of biotin, calcium pantothenate, and nicotinic acid.

Growth rates. The ARGT strains grew much more slowly than strains of either Clavibacter rathayi or Clavibacter tritici. The mean doubling time (the time taken to grow from an optical density of 0.5 to an optical density of 1.0 ) was 18 $\mathrm{h}$ for the ARGT strains, compared with $9 \mathrm{~h}$ for Clavibacter tritici and $8 \mathrm{~h}$ for Clavibacter rathayi.

\section{DISCUSSION}

The bacterium associated with ARGT has been shown to be a species of the genus Clavibacter and to be distinct from other Clavibacter spp. associated with vector nematodes (Anguina spp.) in grasses. It is distinct in its serology (20), allelic profiles (24), bacteriophage sensitivity (21), and the biochemical and physiological properties described in this paper. Also, the results of a preliminary investigation of the fatty acid profiles of two strains suggest that these organisms are significantly different from Clavibacter rathayi (26). There is now sufficient evidence and descriptive information to justify naming a new taxon.

Although the ARGT bacterium is distinct from the other Clavibacter spp., in particular those of similar ecology, the strains which have been isolated are not homogeneous. An allozyme study (24) showed that there is $18 \%$ variation within this species. The greatest differences reported are in adhesion patterns (22); the strains isolated from South Australia and Western Australia differ particularly in their interactions with Anguina spp. other than the normal vector, Anguina funesta. Among the characteristics included in this study one strain differed in the utilization of xylose; otherwise, the reactions were homogeneous. Further investigation may reveal that subspecific or pathovar groupings of strains are justified.

Investigations of toxigenic bacteria that were recently isolated from Agrostis avenacea J. F. Gmelin (blowngrass) in northern New South Wales and from Polypogon monspeliensis (L.) Desf. (annual beardgrass) from the Stewart Range in southeast South Australia showed that these organisms are strains of the Clavibacter sp. described in this paper (15). Allozyme electrophoresis, an enzyme-linked immunosorbent assay, and bacteriophage sensitivity were used to identify these strains. The bacterial infections of these grasses were associated with nematodes, were toxic to livestock, and occurred outside the known range for ARGT and the distribution of $L$. rigidum. The only other reports of toxicity to livestock due to a bacterium associated with an Anguina sp. were from Festuca rubra subsp. commutata Gaudin in Oregon around $1960(10,12)$. The bacterium was not identified, but given that Festuca spp. are also hosts of Anguina funesta (17), it is possible that this bacterium was the same as the organism described here. The reports cited above highlight the need to formally name this bacterium; reference to it as "the Clavibacter sp. associated with ARGT" is clearly inadequate.

The name which we propose is Clavibacter toxicus; this name was chosen because this organism produces corynetoxins (antibiotics belonging to the tunicamycin group) in colonized grasses (7) and is responsible for often fatal poisoning of livestock (19).

Description of Clavibacter toxicus sp. nov. Clavibacter toxicus (tox'i.cus. L. m. toxicus, poison). The description below is based on previously published data, the findings of this study, and our observations. Clavibacter toxicus cells are obligately aerobic, gram-positive, non-sporeforming, nonmotile, coryneform rods that are 0.6 to 0.75 by $1.5 \mu \mathrm{m}$, including a capsule that is 0.08 to $0.14 \mu \mathrm{m}$ thick (1). Surface colonies on 523M agar are convex, smooth, entire, mucoid, and glistening, with light- to mid-yellow pigmentation. In old growth ( $>3$ weeks) pale yellow variants are common and form streaks or convex protrusions, and they maintain their pigmentation in subsequent cultures. From cultured inoculum, single colonies take 5 to 6 days to appear, and from rehydrated anhydrobiotic material obtained from colonized ryegrass colonies take 8 to 14 days to appear. Colonies are often variable in size because the adhesive properties of the mucoid capsule make dispersal to single cells difficult, especially with cells obtained from solid media and colonized plants.

Cell walls contain 2,4-diaminobutyric acid and glycine but no diaminopimelic acid or ornithine (20). Acid is produced from galactose, mannose, and xylose but not from adonitol, dulcitol, erythritol, ethanol, inulin, mannitol, and melezitose. Acid production from xylose is variable. Acetate, glutamate, malonate, succinate, and tartrate are not utilized. The maximum concentration of $\mathrm{NaCl}$ tolerated is $1 \%(\mathrm{wt} /$ vol). Strains do not grow at $37^{\circ} \mathrm{C}$, and the optimum growth temperature is $26^{\circ} \mathrm{C}$ (17). Catalase is produced; oxidase, urease, tyrosinase, and acetoin are not produced. Nitrate is not reduced. Tween 80 and cotton seed oil are not lipolyzed. Unidentified growth factors are required for growth; biotin alone or in combination with nicotinic acid or calcium pantothenate is insufficient. All strains are lysed by the bacteriophage described by Riley and Gooden (NCPPB 3778) (21). The strains are slow growing, with a mean doubling time of $18 \mathrm{~h}$ in $523 \mathrm{M}$ broth at $25^{\circ} \mathrm{C}$ (twice the mean doubling time of the related organisms Clavibacter tritici and Clavibacter rathayi).

Allelic profiles differ by $20 \%$ between strains of Clavibacter toxicus and by at least $85 \%$ from strains of other Clavibacter spp. (24). Polyclonal antiserum raised in rabbits reacts strongly with all strains but cross-reacts at a reduced level with some other Clavibacter spp., Arthrobacter ilicis, and Rhodococcus fascians (20).

All of the strains tested adhere to some populations of the seed gall-forming nematode Anguina funesta, the nematode with which it is most commonly associated in infested ryegrass, and some other Anguina spp., such as Anguina tritici, with which it is not normally associated (22). The 
bacterium colonizes seedheads and nematode galls in ryegrass (19) and occasionally the seedheads of other grasses at the same sites (2). It produces antibiotics that belong to the tunicamycin group (termed corynetoxins) in colonized plants (7); production of corynetoxins declines rapidly during isolation and subculture (16). Inoculation of host grasses has limited success without the vector nematode $(17,23)$.

The type strain is strain CS14 (= ICMP $9525=$ NCPPB 3552). This strain is typical of Clavibacter toxicus in all of the tests shown in Table 2 and produces acid from xylose. Its DNA base composition is $67 \mathrm{~mol} \% \mathrm{G}+\mathrm{C}$. It was isolated in 1984 from ryegrass from a site in Murray Bridge, South Australia, where toxicity to grazing animals had been observed. The site was infested with the vector nematode, Anguina funesta.

\section{ACKNOWLEDGMENTS}

We thank Allen Kerr and Alan McKay for their advice and Janet Gooden for her technical assistance. The key contribution of the providers of reference strains is acknowledged.

Funding was provided by the Australian Meat and Livestock Corporation and the Australian Wool Corporation.

\section{REFERENCES}

1. Bird, A. F., and B. A. Stynes. 1977. The morphology of a Corynebacterium sp. parasitic on annual rye grass. Phytopathology 67:828-830.

2. Chatel, D. L., J. L. Wise, and A. G. Marfleet. 1979. Ryegrass toxicity organism found on other grasses. J. Agric. West. Aust. 20:89.

3. Collins, M. D., and J. F. Bradbury. 1984. Plant pathogenic species of Corynebacterium, p. 1276-1283. In N. R. Krieg and J. G. Holt (ed.), Bergey's manual of systematic bacteriology, vol. 1 . The Williams \& Wilkins Co., Baltimore.

4. Davis, M. J. 1986. Taxonomy of plant pathogenic coryneform bacteria. Annu. Rev. Phytopathol. 24:115-140.

5. Davis, M. J., A. G. Gillaspie, Jr., A. K. Vidaver, and R. W. Harris. 1984. Clavibacter: a new genus containing some phytopathogenic coryneform bacteria, including Clavibacter xyli subsp. xyli sp. nov., subsp. nov. and Clavibacter xyli subsp. cynodontis subsp. nov., pathogens that cause ratoon stunting disease of sugarcane and bermudagrass stunting disease. Int. J. Syst. Bacteriol. 34:107-117.

6. Dye, D. W., and W. J. Kemp. 1977. A taxonomic study of plant pathogenic Corynebacterium species. N. Z. J. Agric. Res. 20:563-582.

7. Edgar, J. A., J. L. Frahn, P. A. Cockrum, N. Anderson, M. V. Jago, C. C. J. Culvenor, A. J. Jones, K. Murray, and K. J. Shaw. 1982. Corynetoxins, causative agents of annual ryegrass toxicity: their identification as tunicamycin group antibiotics. J. Chem. Soc. Chem. Commun. 1982:222-224.

8. Fahy, P. C., and A. C. Hayward. 1983. Media and methods for isolation and diagnostic tests, p. 337-378. In P. C. Fahy and G. J. Persley (ed.), Plant bacterial diseases, a diagnostic guide.
Academic Press, Sydney.

9. Fisher, J. M. 1977. Annual ryegrass toxicity, p. 7-11. In Biennial report of the Waite Agricultural Research Institute, 1976-77. Waite Agricultural Research Institute, Glen Osmond, Australia.

10. Galloway, J. H. 1961. Grass seed nematode poisoning in livestock. J. Am. Vet. Assoc. 139:1212-1214.

11. Hunter, I. S. 1985. Gene cloning in Streptomyces, p. 19-44. In D. M. Glover (ed.), DNA cloning. A practical approach, vol. 2. IRL Press, Oxford.

12. Jensen, H. J. 1961. Nematodes affecting Oregon agriculture. Oreg. Agric. Exp. Stn. Bull. 579.

13. Keane, P. J., A. Kerr, and P. B. New. 1970. Crown gall of stone fruit. Identification and nomenclature of Agrobacterium isolates. Aust. J. Biol. Sci. 23:585-595.

14. Marmur, J., and P. Doty. 1969. Determination of the base composition of deoxyribonucleic acid from its thermal denaturation temperature. J. Mol. Biol. 5:109-118.

15. McKay, A. C., K. M. Ophel, and T. B. Reardon. Unpublished data.

16. Payne, A. L., and P. A. Cockrum. 1988. Production of corynetoxins in vitro by Corynebacterium sp. isolated from annual ryegrass seedheads. Aust. J. Agric. Sci. 39:63-70.

17. Price, P. C. 1973. Investigation of a nematode-bacterium disease complex affecting Wimmera ryegrass. Ph.D. thesis. University of Adelaide, Adelaide, Australia.

18. Price, P. C., J. M. Fisher, and A. Kerr. 1979. Annual ryegrass toxicity: parasitism of Lolium rigidum by a seed-gall forming nematode (Anguina sp.). Ann. Appl. Biol. 91:359-369.

19. Price, P. C., J. M. Fisher, and A. Kerr. 1979. On Anguina funesta $\mathrm{n}$. sp., and its association with Corynebacterium sp., in infecting Lolium rigidum. Nematologica 25:76-85.

20. Riley, I. T. 1987. Serological relationships between strains of coryneform bacteria responsible for annual ryegrass toxicity and other plant pathogenic corynebacteria. Int. J. Syst. Bacteriol. 37:153-159.

21. Riley, I. T., and J. M. Gooden. 1991. Bacteriophage specific for the Clavibacter sp. associated with annual ryegrass toxicity. Lett. Appl. Microbiol. 12:158-160.

22. Riley, I. T., and A. C. McKay. 1990. Specificity of the adhesion of some plant pathogenic micro-organisms to the cuticle of nematodes in the genus Anguina (Nematoda: Anguinidae). Nematologica 36:90-103.

23. Riley, I. T., and A. C. McKay. 1991. Inoculation of Lolium rigidum with Clavibacter $\mathrm{sp}$., the bacteria responsible for toxicity of annual ryegrass. J. Appl. Bacteriol. 71:302-306.

24. Riley, I. T., T. Reardon, and A. C. McKay. 1988. Genetic analysis of plant pathogenic bacteria in the genus Clavibacter using allozyme electrophoresis. J. Gen. Microbiol. 134:30253030.

25. Riley, I. T., T. B. Reardon, and A. C. McKay. 1988. Electrophoretic resolution of species boundaries in seed-gall nematodes, Anguina spp. (Nematoda: Anguinidae), from some graminaceous hosts in Australia and New Zealand. Nematologica 34:401-411.

26. Stead, D. E., and J. E. Sellwood (National Collection of Plant Pathogenic Bacteria). Personal communication. 